\title{
Post-Hatching Development of the Pars Distalis of the Adenohypophysis of the Quail (Coturnix coturnix)
}

\author{
El-Sakhawy, M.A.; Ghareeb, N; El-Bargeesy, G. and Abd El- \\ Rahman, A.
}

Department of Cytology and Histology, Faculty of Veterinary Medicine, Cairo University.

\section{Abstract}

A total number of 95 Japanese quails from hatching up to the actively laying stage were used for studying the post hatching developmental changes occurred in the pars distalis. Quail's pars distalis was found to consist of two lobes (cephalic and caudal). All the cell types in the Quail's pars distalis varied during growth sexual maturity and laying. The gonadotrops (FSH and $\mathrm{LH}$ ) are markedly increased from 4 weeks of age up to laying. Mammotrops appear to increase from 4 weeks till the onset of laying then begin to decrease, however the somatotrops were increased from hatching up to 4 weeks of age only. The thyrotrops became more evident about sexual maturity and laying.

\section{Key words}

Quail, pituitary, pars distalis, developmental changes.

J. Vet. Anat.

\section{Introduction}

Quail production has paid the attention of the breeders as an economical and fast method for animal protein production. These birds have a small size; cheap price; low food consumption as well as they can resist bad environmental conditions and diseases (Belal, 1988).

Quails are chicken like birds; belong to order Galiformes, family phasianidae (Mahnken, 1983 and Enany, 1993).

The anatomical, histological and physiological studies in these birds are essential for evolving a better management. All the cell types of avian pituitary varied in number and morphology during growth, sexual maturation and laying periods (Amin and Gilbert, 1970).

As far as we are aware, there are few references dealing with quail's pituitary developmental changes
Vol 5 No 1, (2012) 1 - 15 
specially those referring to the cellular changes of the pituitary pars distalis during sexual development. On the contrary, many literatures were discussing the cytological structure of the pituitaries in other avian species. So the aim of this work, is to study the micromorphology of the cellular changes of the pars distalis of the adenohypophysis during post hatching growth till the laying stage.

\section{Materials and Methods}

A total number of 95 apparently healthy Japanese quails (Coturnix coturnix) were used in this investigation. They were collected from the quail stock station of Faculty of agriculture, Cairo University, where they were kept and managed under the same conditions of feeding, water supply, temperature, humidity and light exposure per day. Birds were classified into three groups according to the stages of sexual maturation (after Pageaux et al. 1984 and Felouati et al. 1994), immature birds, sexually mature early laying birds and actively laying birds.

After slaughtering the pars distalis of each bird was quickly removed and fixed in Zenker's formol solution. The pars distalis were dehydrated in ascending grades of alcohol, cleared in benzol and embedded in paraffin wax. Thereafter, midsagital sections of the pars dis- talis of all materials were cut from 45 micrometers.

\section{The following staining methods were adopted:}

1. Harris haematoxylin and eosin as a general staining method (Drury and Wallington, 1980).

2. Crossmon's trichrom stain for staining collagenic fibers, smooth muscle fibers, smooth muscle, fuchsinophilic and orangophililc substances (Crossmon, 1937).

The pars distalis were specially stained for identification of the different cell types on the basis of their chemical constituent, by the following methods:

1. Aldehyde fuchsin - Periodic acid schiff - Orange G (AF- PAS- OG) for differentiation of thyrotrops, gonadotrops, somatotrops and lactotrops (Elftman, 1959).

2. Peracetic acid- Alcian blue $(\mathrm{pH}$ 0.2 )- Periodic acid schiff -Orange $G$ (PA- AB - PAS - OG) for demonstration of thyrotrops, somatotrops, gonadotrops and lactotrops (Heath, 1965).

3. Aldehyde thionin- Periodic acid schiff -Orange G (Ath-PAS-OG) for demonstration of thyrotrops, $\mathrm{FSH}$ gonadotrops, LH gonadotrops, corticotrops (Ezrin and Murray, 1963).

4. Azocarmine-Aniline blue- Orange $G$ (Heidenhain's azan modification) for differentiation somatotrops from 
lactotrops (Bancroft and Stevens, 1982).

\section{Results}

The pars distalis was consisted of two lobes (cephalic and caudal lobes). On the first day of life, the majority of their cells were the chromophobes. Wide blood sinusoids were irregularly distributed in a numerous number in between cells. Mitosis was frequent (Fig 1). The cells of pars distalis were arranged in cords and clusters. The numerous chromophobic cells were irregularly distributed all over the pars distalis in the form of groups and cords.

At one week age, few blue-stained thyroptropic cells (PA. AB. PAS.OG \& Ath. PAS. OG techniques) were hardly detectable in both lobes. They were more or less pyramidal or polygonal in shape, with sparse cytoplasmic granules and oval or rounded eccentrically located nuclei. Publish large FSH cells were only visible in the cephalic lobe. They were oval or elongated in shape with fine purple granules and large vesicular eccentric nuclei. LH gonadotropes were firstly detected at 7 days old. They appeared sporadically together with the other chromophils in the part of the caudal lobe, which was nearer to the ce- phalic one. These cells were large oval in shape, and their cytoplasm contained coarse PAS positive granules. Their nuclei were relatively large, eccentric and lightly stained with clear nucleoli.

Corticotropic cells were undetectable during the first week of life.

The somatotropic cells appeared in clusters and cords throughout the caudal lobe only. Most of these cells contained sparse fine yellow cytoplasmic granules (Ath. PAS. OG stain). Their nuclei were large, spherical, eccentrically located and vesicular.

\section{Pars distalis of 2-3 weeks chicks}

The cells considered to be FSH gonadotrops were increased in number. Their cytoplasm stained more intensely (Fig 2). The LH gonadotrops were few in number and their cytoplasm appeared pale red (AF- PAS- OG \& Ath-PAS-OG techniques). These cells showed some affinity to orange $G$ stain (Fig. 3). The lactotropic cells were firstly detected at 2 weeks old age. These cells were found distributed singly in the center of pars distalis, in the both lobes of the gland. They were few in number elongated or oval in shape. Their nuclei were rounded vesicular and eccentric. The cytoplasm contained few orange stained granules (PA- AB - PAS - OG tech- 
nique) or slightly red with Heidenhain's azan stain (Fig 4). The somatotropic cells showed marked increase in their number, size and staining affinity. Their cytoplasmic granules stain yellow with all of the used staining techniques. Regarding to the thyrotrops most of their detectable cells were polygonal or pyramidal in shape and contain vesicular nuclei surrounded by granulated cytoplasm. Some follicles showed increase in the amount of colloid-like material in their lumina.

\section{Pars distalis of immature birds from 4-6 weeks}

During this period, the pars distalis showed characteristic changes in the gonadotrops. The FSH gonadotrops further increased in their number,size and staining intensity. They were numerous in the cephalic lobe. They were arranged peripherally in the cell clusters abutting the sinusoids. The cells were usually oval or elongated with large eccentric and lightly stained nuclei. Their cytoplasm was filled with numerous intensely stained fine and coarse purple granules (Ath-PAS-OG staining technique). Few cells were still small in size and contain few cytoplasmic granules (Fig 5). The LH gonadotrops increased in number especially in the caudal lobe of 6 weeks old birds. They appeared elongated columnar with large spherical light nu-

J. Vet. Anat. clei. The perinuclear cytoplasm was intensely stained and contained abundant coarse PAS positive red cytoplasmic granules. The thyrotropic cells somewhat increased in number. Few blue cytoplasmic granules with (PA- AB - PAS - OG technique) were observed. The lacotropic cells increased in number and staining intensity. They appeared large oval or rounded contain cytoplasmic granules stained orange with (Ath-PAS-OG or PA$A B$ - PAS - OG technique) or red with (Heidenhain's azan stain). The somatotropic cells also increased in number and staining intensity in 4 weeks old chicks but not further increased up to 6 weeks of age. They appeared in clusters with $\mathrm{LH}$ gonadotrops in the cranial part of the caudal lobe (Fig. 6). Cords or cluster formed mainly of somatotropic cells only were seen in the caudal part of the caudal lobe. They appeared oval or rounded and contained peripheral large spherical nuclei. Their cytoplasmic granules stained yellow (PA- AB - PAS - OG technique). The chromophobes somewhat reduced in number.

\section{Sexually mature birds \\ Pars distalis of early laying birds (from 7 to 9 weeks)}

All the chromophil cell types reach their maximum mature form in both size and staining affinity. The cells 
in the cephalic lobe were usually arranged into cell cords and clusters, and the blood sinusoids appeared wide and filled with blood. FSH gonadotrops were numerous. They showed two main types. The first were those cells with densely granular cytoplasm, and the second ones showed sparsely granular cytoplasm. They were usually arranged along the blood vessels (Fig 7). The LH gonadotrops were further increased in number. They were found in clusters together with the lactotrops. Abundant thyrotropic cells were observed during this period. They were always distributed within the cell clusters of the cephalic lobe and the cell cords of the caudal one (Fig 8). The lactotropic cells were increased in their number than in 6 weeks aged chicks. Most of these cells were found in the cephalic lobe and few were observed in the adjacent clusters of the caudal lobe (Figs 9 and 10). The somatotropic cells did not show any noticeable changes than those of 6 weeks old birds. The corticotropic cells were very few in number. They were detected only within the cell clusters of the cephalic lobe. Their cytoplasm was filled with abundant fine PAS positive granules. Their nuclei were rounded and peripheral (Fig 11).

\section{Pars distalis of mature actively laying birds}

The pars distalis of actively laying hens showed a majority of chromophils with few numbers of chromophobes. Numerous FSH gonadotrops of both types (granulated and degranulated) were seen in the cephalic lobe of pars distalis. The degranulated cells were the predominant type in most of the hens (Fig 12). Few LH gonadotrops were found in close association with FSH gonadotrops in the cell clusters near the cephalic lobe. They were markedly large, elongated; contain coarse and abundant dark red PAS positive granules. They were also seen peripherally in the cell clusters or follicles (Fig 13). The thyrotropic cells were further increased in number in the cell cords and clusters of both lobes and might be sporadically distributed or found in groups. Many cells contain abundant cytoplasmic granules, while others contain a few (Fig 14). The somatotropic cells simulated those present in the 7-9 weeks hens. The lactotropic cells contained few granules and appeared lightly stained (Fig 15).

\section{Discussion}

In the present work, the developmental changes in the pituitary pars distalis of the post-hatching quails (Coturnix coturnix) were studied. 
Amin and Gilbert (1970) in chicken, explained that the development of gonadotropic cells was always associated with the onset and maintenance of sexual maturity.

\section{Immature chicks from 1 up to 3 weeks old}

Early in the post hatching life, our study revealed few sparsely granulated FSH gonadotrops. These cells showed gradual and slight increase in their number and staining intensity up to three weeks of age. Besides, the LH gonadotrops number was also increased with advanced age but they were always fewer in number than the FSH ones. Similar findings were observed by Wilson (1952) and Amin and Gilbert( 1970) in hens. Pageaux et al., (1984) in quail demonstrated a stable low level of plasma estrogen during the first three weeks of life. Also they added that, the progesterone level shows a sharp decrease in between 14 and 21 days of life. This might imply low levels of FSH and LH secreted during this period and is consistent with the low number of both FSH and LH gonadotrops observed in our immature quail.

As mentioned before by Amin and Gilbert (1970) in fowl, VasilatosYounken (1988) and Malamed et al.( 1997) in chicken, and in association with the rapid growth of the birds during the first three weeks, we recorded a gradual increase in the size, number and staining intensity of the somatotrops. This was also confirmed by Scanes et al. (1992) in chicken who recorded a post hatching continuous rising in the circulating $\mathrm{GH}$ up to 2 weeks of age then begins to decrease after that. So we could speculate that the sparsely granular somatotrops recorded in the earlier ages of our study might be the active form. Also the increase of staining intensity and their number up to 4 weeks of age might indicate gradual decrease in the hormonal release by these cells. During the first weeks of life, we did not record any lactotropic cells, and they were seldom recognized during the second and third weeks of life. Similar findings were recorded in young brown leghorn birds up to 16 weeks of age (Amin and Gilbert, 1970).

\section{Immature chicks from 4 up to 6 weeks old}

In the present study numerous FSH gonadotrops were recorded in the cephalic lobe of pars distalis at 4 weeks of age, while LH gonadotrops were gradually increased up to 6 weeks of age. These results were in accord with Amin and Gilbert( 1970) in brown leghorn hens who recorded the increase in number of $\mathrm{FSH}$ gonadotrops at 20 weeks, while the LH gonadotrops showed detectable 
increase after this age as the ovarian follicular growth proceeded. This would explain the sequence of increase in $\mathrm{FSH}$ and $\mathrm{LH}$ gonadotrops at 4-6 weeks of age in this study. This is also confirmed by Pageaux et al.( 1984) in quail chicks who recorded the increase of the plasma estrogen level in chicks over 21 days of age; while the progesterone level begins to rise over 28 days of age.

During this period we observed that the number and staining intensity of the somatotropic cells were increased in four weeks chicks which became stable up to 6 weeks of age. Similar findings were recorded in chickens from 18-26 weeks of age (Malamed et al. 1997). However, Vasilatos-Younken (1988) and Malamed et al.( 1993) in chicken noticed a decrease in somatotrops number with the beginning of sexual maturation at about 24-30 weeks; their finding were consistent with a low level of plasma $\mathrm{GH}$ which is found in chicken during this period (Scanes et al. 1992).

Thyrotrops were not obviously increased in number or cytoplasmic granulation in this period from 4-6 weeks of this study. Similar findings were recorded by Amin and Gilbert (1970) in fowl, who found slow increase in thyrotropic cells with ad- vanced ages. In agreement with Amin and Gilbert, (1970) in brown leghorn hens, an increased number of more granular lactotropic cells were observed from 4-6 weeks of age (during the rapid growth phase of ovarian follicles).

The estrogen causes lactotropic cells proliferation in pituitary cells culture by a direct action on lactotrops (Lieberman et al. 1982). In addition, prolactin acts to promote growth in pigeons and in chicken (Huble, 1956).

\section{Sexually mature birds \\ Early laying birds}

With the beginning of egg laying, this study revealed a secretory cycle of activity in both FSH and LH gonadotrops which appeared in the form of densely and sparsely granulated cells. These results are in accord with the findings of Amin and Gilbert (1970) in hens. This cycle was also demonstrated by Nelson et al. (1965) Bullock and Nalbandov (1967) and Tanaka and Yoshioka (1967) in chicken. This was confirmed by Senior and Cunningham (1974) in laying hens.

The present study revealed an obvious increase of thyrotropic cells with the onset of egg laying. This was in agreement with Amin and Gilbert (1970) in the fowl. The in- 
crease in estrogen secretion during this period promotes thyroid function in chicken (Sturkie, 1965). So that the increased number of thyrotropic cells during this period might be related to a markedly increased estrogen level produced by the maturing ovarian follicles in quail (Pageaux et al., 1984).

In accord with, Malamed et al. (1997) in chicken there was no difference between those of early laying quails and those of 4-6 weeks old. During this period we revealed that the lactotropic cells showed increase in their number and staining affinity. As the estrogen increases up to certain levels in hens, it causes proliferation of these cells and decrease prolactin output (Amin and Gilbert, 1970). So we could suggest that the increase of estrogen leads to the increase in number of lactotropic cells, and their granules which appear more prominent.

Corticotropic cells were hardly detected in the cephalic lobe of pars distalis in our study. The same results were reported by Hodges (1981) in avian species who proved that these cells are not easily distinguishable in the normal hypophysis but become clearly visible in the center of the cephalic zone after adrenalectomy.

\section{Actively laying birds}

Further increase in both gonadotrops (FSH and $\mathrm{LH}$ ) was observed with the increased number of sparsely granulated form of these cells in most of quail hens. This increased number of gonadotropic cells is in accord with Amin and Gilbert (1970) and Stockell-Hartee and Cunningham( 1971) in hens.

The estrogen and progesterone plasma levels appeared to increase with the increase of egg production in quail (Pageaux et al., 1984). So we can suggest that the increased number of sparsely granulated gonadotrops might indicate increase in the activity of these cells in association with the increase of egg production.

With regard to the localization of gonadotropic cells we are in accord with Tixier-Vidal $(1965,1968,1972)$ in ducks, quail and pigeon; Jover and Rivera (1970) and Ismail (1994) in chicken who found that the $\mathrm{LH}$ gonadotrops are localized in the caudal lobe and the FSH ones are found in the cephalic lobe only. On the contrary, the FSH and $\mathrm{LH}$ cells are recorded in both lobes in hens (Pantic and Skaro, 1974); in quails (Wada, 1975) and in Chicken (Mikami, 1983). 
The present investigation revealed further increase in thyrotropic cells of actively laying hens. This is in accord with Amin and Gilbert (1970) in hens who suggested that this increase in thyrotrops might reflect general increase in metabolic rate, which is associated with the reproductive activity.

With the increased egg production, there were a decrease in both number and staining affinity of lactotrops. Similar finding was reported by Amin and Gilbert (1970) in hens.

Nakajo and Imai (1961) in chicken found that the prolactin content of the pituitary gland tends to be inversely proportional to the level of FSH and LH.

We are in accord with Amin and Gilbert (1970) and Stockell-Har-tree and Cunningham (1971) in hens that lactotrops were detected in both lobes of pars distalis, and we added that they were always found in the middle third of the gland.

In actively laying quail hens, our study showed unchanged number of somatotrops than early laying hens this finding was in agreement with Amin and Gilbert (1970) and Malamed et al. (1985, 1988, 1993, 1997) in chicken. The latter author confirmed that somatotrops from adult birds contain a less somatotropin than those of the juveniles.

The pars distalis in sexually mature laying quail hens showed a numerous wide blood sinusoids rich in blood. These findings agree with Ismail (1994) in fowl who recorded highly vascularized pars distalis in laying hens and they considered this phenomenon as an indication of the increased activities during this period.

\section{References}

Amin, S.O. and Gilbert, A.B.(1970):

Cellular changes in the anterior pituitary of the domestic fowl during growth, sexual maturity and laying. $\mathrm{Br}$. Poult. Sci, 11: 451- 458.

Bancroft, J.D. and Stevenes, A.

(1982): Theory and practice of histological techniques, $2^{\text {nd }} E d$. Churchill Livingstone, Edinburgh, London, New York.

Belal, R.M. (1988): Quail production in farms and modified instructions. Dar El-Nasr for Islamic Press, Shubra, Egypt.

Bullock, D.W. and Nalbandov,

A.V. (1967): Hormonal control of the hen's ovulatory cycle. J. Endocrinol. 38: 407415.

Crossmon, G. (1937): A modifica 
tion of mallory's connective tissue stain with discussion of principle involved.Anta. Rec., 69: 33 - 38.

Drury, R. A. B. and Wallington, E.A. (1980): Carleton's histological technique. Fourth Edition Oxford University Press, New York, Toronto.

Elftman, H. (1959): Combined al dehyde-fuchsin and periodic acid schiff staining of the pituitary. Stain Tech., 34: 7780.

Enany, M.M. (1993): Egyption birds, General Egyptian Press for Book 10432.

Ezrin, C. and Murry,S.(1963): The cells of the human adenohypophysis in pregnancy, in cytologic de L'Adenohypophyse. J. Benoit and C. Da Lage, ed. Ed. Du CNRS, Paris, pp. 183 - 199.

Felouati, B., Pageaux, J., Fayard, J., Lagarde, M. and Laugier, C.(1994): Oestradiol-induced changes in the composition of phospholipid classes of quail oviduct: specific replacement of arachidonic acid docosahexaenoic acid in alkenylacyl-

glycerophosphoethanola-

mine. Biochem. J. 301: 361366.

Heath, E. (1965): Application of the performic acid, alcian blue, periodic acid Schiff, orange $G$ stain to the section of the pituitary gland from domestic animals. Am. J. Vet. Res., 26: 368.

Hodges, R.D. (1981): Endocrine glands. Pp. 149 - 234 in: Form and function in birds. Vol. 2. A.S. King and J. McLellad, ed. Academic press, London, UK.

Huble, J. (1956): Gonadal and hypophyseal interactions on the young fowel. Acta endoocrinol., 23: 101.

Isamil, H.I.M. (1994): Studies on follicle stimulating hormone during moult of laying fowls. M. Sc. Thesis Faculty of Agriculture, Zagazig University. Jover, A., Rivera,J.M. (1970): Ultra estructura de las celulas gland ulares en la adenohipofisis del pollo (Gallus domesticus). Arch. Zoottec. 19, 3 - 18.

Liberman, M.E., Maurer, R.A., Claude, P. and Gorski, J. (1982): Prolactin synthesis in primary culture of pituitary cells: Regulation by estradiol. Mol. Cell. Endocrinol. 25: 277- 294.

Mahnken, J. (1983): Feeding the bird, Garden way publishing, Pownal, Vermont 05261.

Malamed, S., Deaver, D., Perez, 
S., Gibney, J. and Scanes, C. G. (1997): Quantitave studies of chicken somatotrophs during growth and development by morphometry, immunocytochemistry and flow cytochemistry. General and Comparative Endocrinology 108: 25 - 34.

Malamed, S., Gibney, J., Ghain, L.D., Perez, S. and Scanes, C. G. (1993): Immunocytochemical studies of chicken somatotrophs and somatotroph granules before and after hatching. Cell Tissue Res. 272: 369 - 374.

Malamed, S., Gibney, J.., Loesser,

K. E. and Scanes, C. G. (1985): Age related changes of the somatotrophs of the domestic fowl Gallus gallus. Cell Tissue Res. 239: 87- 91. Malamed, S., Gibney, J. and

Scanes, C. G.(1988): Immunogold identification of the somatotrophs of domestic fowl of different ages. Cell Tissue Res. 251: 581- 585.

Mikami, S. (1983): Avian adenohy pophysis: recent progress in immunocytochemical studies. Pp 39 - 56 in Avian Endocrinology: Environmental and Ecological Perspectives. S. Mikami, K. Homma and M. Wada, ed. J apan Sci. Soc. Press, Tokyo, Japan/
Springer-Verlag, Berlin, Germany.

Nakajo, S. and K. Imai, (1961):

Gonadotrobin content in the cephalic and caudal lobes of the anterior pituitary in the laying, non-laying and broody hens. Poultry SCl., 40, 739.

Nelson, D. M., Norton, H. W., and Nalbandov, A. V., (1965): Changes in hypophysial and plasma LH levels during the laying cycle of the hen. Endocrinology 77: 889-896.

Pageaux, J. F., Laugier, C., Pal, D. and Pacheco, H., (1984): Development of the oviduct in quail during sexual maturation in relation to plasma concentrations of oestradiol and progesterone. J. Endocr. 100: 167-173.

Pantic, V. and Skaro, A. (1974):

pituitary cells of roosters and hens treated with a single dose of estrogen during embryogenesis or after hatching. Cytobiol. 9, 72-83.

Scanes, C. G., Radecki, S. V., and Malamed, S. (1992): Mechanisms involved in the avian species. Life Sci. 28: 28952902.

Senior, B. A. and Cunningham, F. J., (1974): Estradiol and LH during the ovulatory cycle of hen. J. Endocrinol. 60, 201. 
Stockell-Hartree, A. and Cun ningham, F. J. (1971): The pituitary gland. Pages 434437 in: Physiology and Biochemistry of the domestic fowl. Vol.1, Academic Press. London. New York.

Sturkie, P.D. (1965): Avian physiol ogy, New York, Comstock Publishing Associates, Cornel University Press.

Tanaka, K. and Yoshioka, S. (1967): Luteinizing hormone activity of the hen's pituitary during egg-laying cycle. Gen. Comp. Endocrinol. 9 : 374 - 379.

Tixier-Vidal, A.( 1965): Caracteres ultrastructuraux des types cellulaires de l'adenohypophysis du canard male. Archs Anat. Microsc. Morph. Exp. 45: 719 - 780.

Tixier-Vidal, A.( 1968): Influence de la testosterone sur la cytology et l'ultrastructure de l'adenohypophysis du ca- nard male. Arch. Anat. Histol. Embrol. Norm. exp. 51, 709 - 717.

Tixier-Vidal, A.( 1972): Ultrastruc tural feature of gonadotrophic pituitary cells in culture. Symp. Biol. Hung. 14, 43 - 58.

Vasilatos-Younken, R . (1988):

Posthatch ontogeny and sex related differences in somatotroph numbers in chicken adenohypophysis. Poultry Sci . 67: 487- 492.

Wada, M. (1975): Cell types in the adenohypophysis of the Japanese quail and effect of injection of luteinizing hormone. Cell Tiss. Res. 159: 167 - 178.

Wilson, M.E. (1952): The embryo logical and cytological basis of regional patterns in the definitive epithelial hypophysis of the chick. The Am. J. of Anat. 91: 1 - 40. 

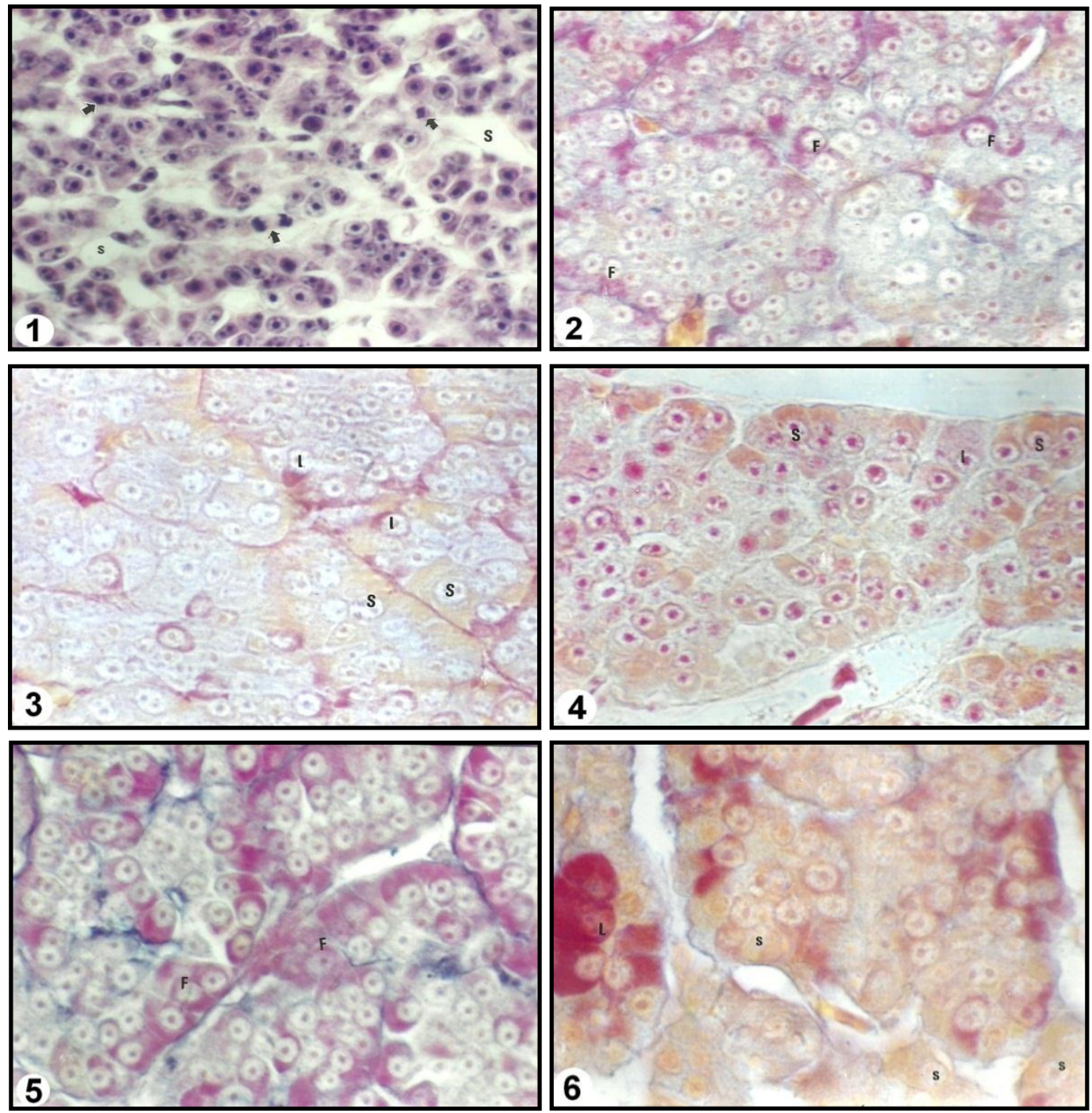

Fig (1): Section from pars distalis of one day old chick showing a mitotic division in all cell types (arrows). Notice the wide and irregular blood sinusoids (S). H\&E X800

Fig (2): Section in the cephalic lobe of 2 weeks old chick showing increased number of purple FSH gonadotropic cells (F). PA- AB - PAS - OG X800

Fig (3): Section of cudal lobe of 2 weeks old chick showing red LH gonadotropic cells (1) and yellow somatotropic cells (S). AF- PAS- OG X800

Fig (4): Section at the caudal lobe of 3 weeks old chick showing yellow somatotropic cells (S), and few sparsely granulated lactotropic cells (1). Heidenhain's azan stain X800

Fig (5): Section in the cephalic lobe of 4 weeks old quail chick showing numerous purple FSH gonadotropic cells $(F)$. Ath-PAS-OG X800

Fig (6): Section at the caudal lobe of 6 weeks old quail showing yellow somatotropic cells (S) and red densely granulated lactotropic cells (L). PA- AB - PAS - OG X1024

J. Vet. Anat. 

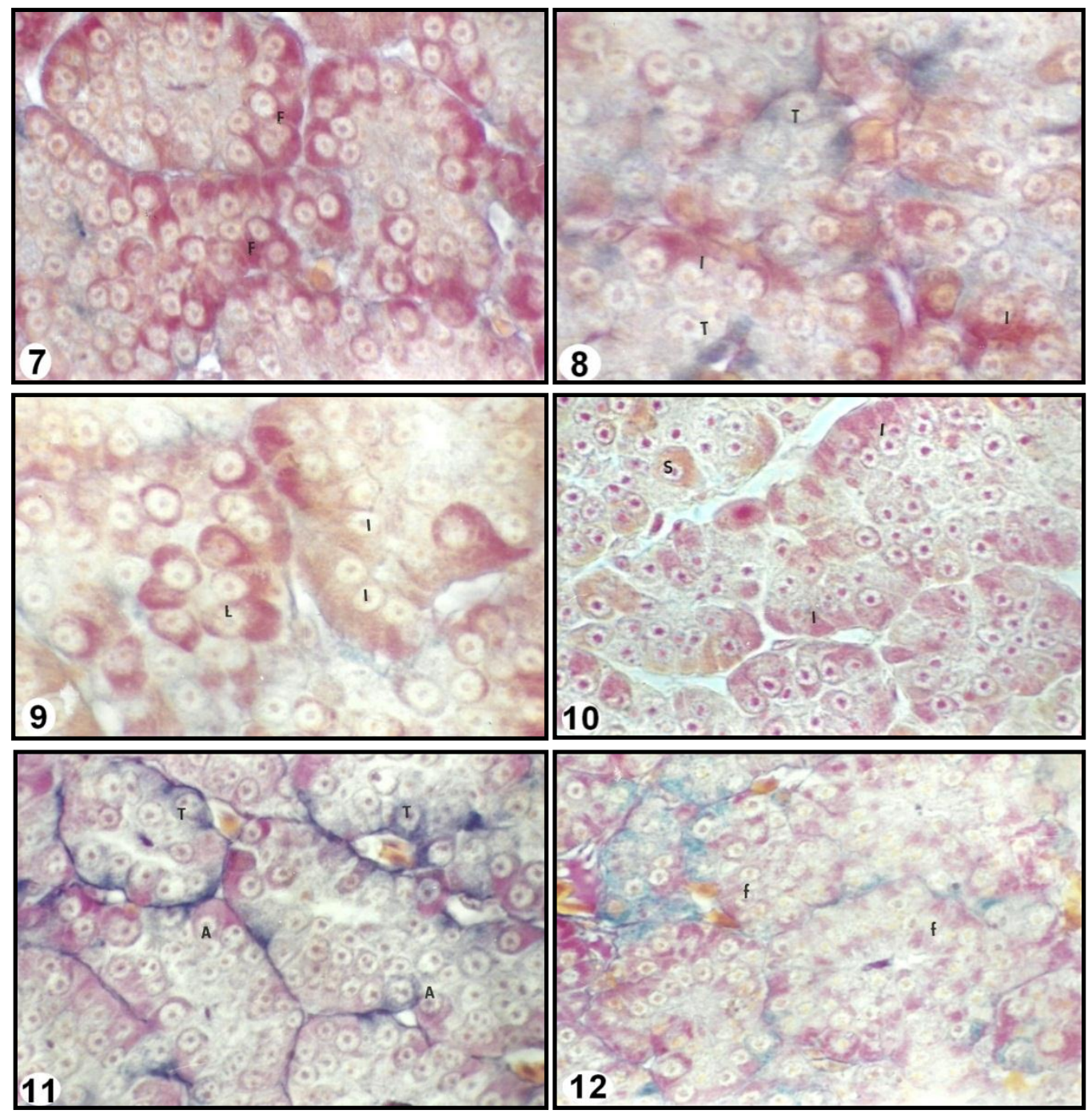

12

Fig (7): Section in the cephalic lobe of an early laying quail hen showing many FSH gonadotropic cells $(F)$. PA- AB - PAS - OG X800

Fig (8): Section in the caudal lobe of an early laying quail hen showing red $\mathrm{LH}$ gonadotropic cells (1) some of them are sparsely granular and blue thyrotropic cells (T). PA- AB - PAS - OG X1024

Fig (9): Section in the cephalic lobe of an early laying quail hen showing many large oval lactotropic cells (1), and LH gonadotropic cells (L). PA- AB - PAS - OG X1024

Fig (10): Section in the caudal lobe of an early laying quail hen showing increased red lactotropic cells (1) beside yellow somatotropic cells (S). Heidenhain's azan stain X800

Fig (11): Section in the cephalic lobe of an early laying quail hen showing corticotropic cells (A) and blue thyrotropic cells (T). Ath-PAS-OG X800

Fig. (12): Section in the cephalic lobe of laying quail hen showing numerous degranulated FSH gonadotrops (f). PA- AB - PAS - OG X800

J. Vet. Anat. 

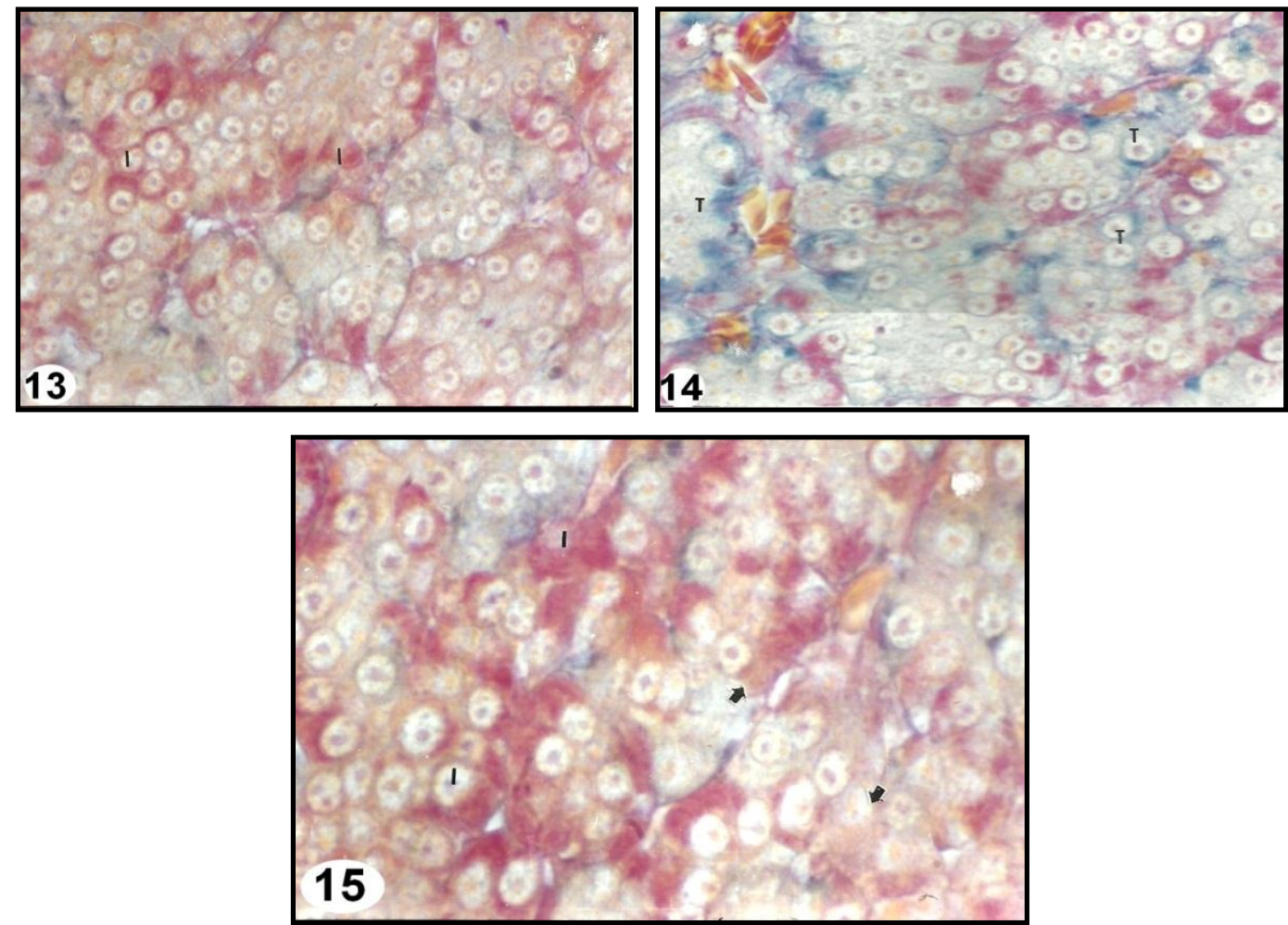

Fig (13): Section in the caudal lobe of actively laying quail showing many red LH gonadotropic cells (1). PA- AB - PAS - OG X800

Fig (14): Section in the caudal lobe of actively laying quail near the cephalic lobe showing increased number of granulated thyrotropic cells (T). PA- AB - PAS - OG X800

Fig (15): Section in the caudal lobe of actively laying quail showing few less granular lactotropic cells (arrows) and many LH gonadotrops (1). PA- AB - PAS - OG X1024 